DOI: $10.15503 /$ jecs20142.154.165

\title{
APPLICATION OF TARGET COSTING METHOD IN THE HOSPITALITY INDUSTRY
}

\author{
ANDOR PAJROK \\ Institute of Business Sciences, Eötvös József College, \\ Bajcsy-Zsilinszky 14, H-6500 Baja, Hungary \\ E-mail address: pajrok.andor@ejf.hu
}

\begin{abstract}
Traditional approaches to managing costs are based on the costs that are the result of existing capabilities and resources in the company. Adding to these costs a specified margin or profit, leads to the sales price. If the market is not ready to accept such a selling price, managers need to find opportunities for rationalization and cost reduction. Target cost management begins the process of managing the sales price and the planned profit that the market can accept, and only then is it possible to determine the cost of the product. In the planning phase of the product and the manufacturing process the approach is to finding a method to lower costs and to reduce them as much as possible. The aim this of study is to investigate the application of target (strategy) cost accounting methods in the Hospitality Industry.
\end{abstract}

Keywords: Target Costing, Strategy Accounting, USALI.

\section{INTRODUCTION}

In the second half of the 20th century companies faced with a strong competitive business environment, to satisfy all large and varied customer needs have turned to production of small series of diversified products. Due to the ever growing variety of products, strengthening competition and the need for cost reduction, are methods of target costing which captivated the world's attention. Authors (Tanaka, 1993; Fiel, Yook, \& Kim, 2004) argue for the method of target costing which originated in Japan, a preliminary calculation model developed by Toyota in 1965 .

According to the authors (Sakurai, 1989; Ansari, Bell, Cypher, Dears, Dutton, Ferguson, Hallin, Marx, Ross, \& Zampino, 1997) the target costing model is a complex concept and cost management, which includes a range of instruments for planning and decision making on the cost structure of the product or service. The authors (Horvath, 
Gleich, \& Schmidt, 1998; Cooper, \& Slagmulder, 2002) agreed that the target costing model arising as a response to the demands of price-sensitive consumers, represents a superior approach to reduce and control costs compared to the traditional concept of cost accounting. Other accounting experts (Monden, 1995) emphasize the aim of application of the target costing model. According to them the method is applied in the earliest stages of production, or in the phase of planning and development, with the aim of adapting products or services to the needs and desires of customers.

\section{DEFINITION AND IMPLEMENTATION OF TARGET COSTING METHOD}

The target costing method was first applied by the Japanese car maker "Toyota", and as a result of achieved success the model quickly spread between Japanese companies. The most significant growth was during the first oil crisis in 1973, when the target costs used as a management technique which costs can be reduced as much as the cost of production. In tnhe 80's, target costing method was becoming more popular in England and Germany, whence came numerous studies related to that concept. The original Japanese name for the model is "Gence Kikaku" meaning the process of planning and cost management. In the literature we can find several definitions, one of most cited indicates that it is a system that supports the process of lowering costs in development and design of the new model (product), the full model change or minor changes to the model (Monden, \& Hamada 1991).

Ronald W. Hilton (2008) defines the target costing method as projected long-term costs that will allow entry and survival of products on the market and gaining competitive advantages for the company. Target costing is determined by the target costs based on previous research of price at which the product or service can sell in to the market, then it defines the target price subtracts the required profit to arrive at the target cost. Kim Langfield-Smith, Helen Thorne and Ronald W. Hilton (2006) state that the target costing method represents a system of profit planning and cost management which determines the amount of allowable costs of the product during its life cycle which generate the desired profit to the company with a target selling price. They clearly indicate that the target costing is method of determining the costs of production, but also a technique to manage costs. According to Ray H. Garrison, Eric W. Noreen and Peter C. Brewer (2004) target costing represents a determination of maximum allowable cost of a new product and then develops prototype products that will be profitable with the maximum amount of target costs. Robin Cooper and Regine Slagmulder (2002) argue with the above mentioned and give almost the same definition. According them is a structured approach to determining cost at which a particular product with a specified functionality and quality must be produced to achieve the desired level of profitability throughout its life cycle at the expected selling price. They emphasise the design phase of the product or service, given that includes the defining characteristics of the product design and costs themselves. Shahid Ansari, Janice Bell, Thomas Klammer, Carol Lawrence (1997) in their research emphasized implementation of target costing method as an effort to achieve a competitive advantage. Since the implementation of target costing method is triggered 
by the market, its increasingly sophisticated demands and competitive business conditions, it is a basic feature of understanding market needs and attempts to connect strategic component of products into one unit while respecting the demands of those for whom it is intended.

Regardless of the different definitions of target costing method we can conclude that it represents a market-orientation, encouraging cost competitiveness in the way that the calculation takes into account all costs of the product or service during its life cycle.

The simplified model for determining the target cost of the new product is based on planning and designing products to meet customer requirements, defining the target cost of the product, comparing the target cost and the standard cost of the product and the process of redesigning the product if the target costs exceed the standard.

Authors (Ansari, Bell, Klammer, \& Lawrence, 1997; Cooper, \& Slagmulder, 2002) argue that the first element of target costing method is understanding and identifying consumer requirements, including the characteristics and costs of competing products. The model of target costs is therefore applied already in the design phase of the product to be created that will meet the demands of customers and be competitive in the market. Collecting information from the market is a very important step in the process of determining the target cost and product development. The characteristics of the product that the company will offer the market should meet the expectations of customers in terms of price, quality, delivery, service capabilities, technology and other characteristics.

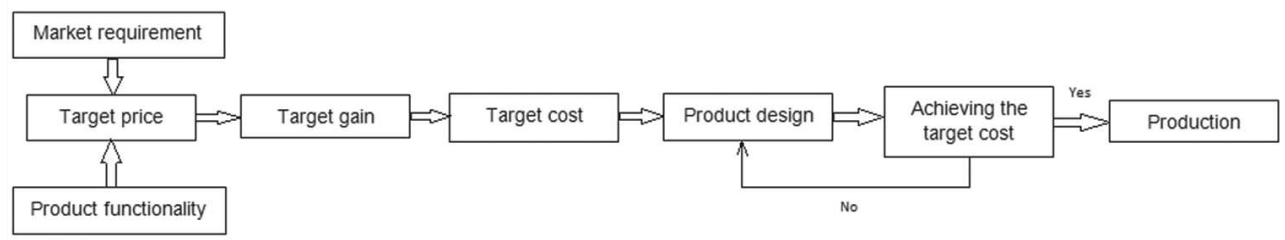

Fig. 1. General summery of the Target costing process

Source: S. Ansari et al. (1997).

Since the target costs are based on the market price of similar products, the process of their calculation begins by examining the market and analyzing the preferences of potential buyers for the properties of the product. Based on the results of market research collaborators in research and development are defined in the specified product. The actual start of the determination of target costs is to determine the selling price for a new product. In contrast to the traditional understanding of the costs, while reducing the cost of existing product adds a desired gain (profit margin) and as a result get the sales price, according to the modern principle based on the market price which is reduced to the desired gain and the difference relates to the permissible target costs. 
Determination of the target cost of the product depends on numerous factors, some of which are a type of product, technical specifications and production requirements, consumers, market prices, costs, production and more. The concept of target cost management is developed with different methods of calculation, namely (Tani, \& Kato, 1994):

1. subtraction method (so-called "market into company"),

2. method of addition (so-called "out of company"),

3. integrated method (so-called "into and out of company").

Subtraction method (market into company) is based on calculating the cost or price that consumers are willing to pay and the target gain. Subtracting the value of the target price of the target gain is the calculated level of permitted costs that the market is ready to accept. Based on the existing product and process technology professional departments establish standard costs. Target costs will be determined between the permitted and the standard cost. In practice, the most commonly used is precisely this method of calculating target costs. However, it can set the allowable costs at such a low level that the company can hardly achieve.

Target selling price
-target gain
$=$ Allowable cost by market
-standard cost
-target difference
$=$ Target cost

Fig. 2. Calculating the Target cost by Subtraction method Source: Authors' edition

The method of addition (out of company) is based on existing technologies and data on already incurred costs of similar products that the company produces. The target cost is achieved by improving the methods of production or by redesigning previous product options. Target cost method of adding is computed as follows:

\section{The actual cost is characteristic for all products + specific costs to the selected product $=$ Target cost}

Figure 3. Calculating the Target cost by Addition method Source: Authors' edition.

However, a major drawback of this method is that it ignores the demands of the market. The integrated method is a combination of methods subtraction and addition methods. This method is used in most European countries. 


\section{APPLICATION OF TARGET COSTING METHOD IN HOTELS}

Application of Target costing method in this article is shown through an example, the process is based on S. Ansari et al. (1997). Envisage a Hotel which wants to launch a mini bar service in hotel rooms. Planned profit is $15 \%$ of the sales price. The Mini bar consists of four components: box, shelves, ice cube tray and cup holder.

Firstly, to determine the target cost of a specified service the marketing department has to prepare a market research to find out the specific requirements of potential customers in terms of mini bar properties. Assume that market analysis has allocated five most important characteristics of mini bar, which are ranked according to importance in making purchasing decisions.

\begin{tabular}{|c|c|c|c|c|c|c|c|}
\hline \multirow{2}{*}{$\begin{array}{l}\text { Properties } \\
\text { of service }\end{array}$} & \multicolumn{5}{|c|}{$\begin{array}{l}\text { Very important } \\
\text { Less important }\end{array}$} & \multirow{2}{*}{$\begin{array}{c}\text { Scores } \\
\text { (preferences) }\end{array}$} & \multirow{2}{*}{$\begin{array}{c}\text { Share in } \\
\text { the overall } \\
\text { assessment (\%) }\end{array}$} \\
\hline & 1 & 2 & 3 & 4 & 5 & & \\
\hline Wide choice & $x$ & & & & & 1 & 33,33 \\
\hline Design & & $x$ & & & & 2 & 26,67 \\
\hline Dimensions & & & & $x$ & & 4 & 13,33 \\
\hline $\begin{array}{l}\text { Economic } \\
\text { characteristics }\end{array}$ & & & & & $x$ & 5 & 6,67 \\
\hline Utilization & & & $x$ & & & 3 & 20,00 \\
\hline Total & & & & & & & 100,00 \\
\hline
\end{tabular}

Tab. 1. Preferences of mini bar features

Source: Authors' edition based on S. Ansari et al. (1997).

The table shows the preferences of customers regarding the characteristics of the mini bar. Customers agreed that their decision to choose mini bar service is mostly affected by the wide choice of mini bar and its design. Market research has shown that customers are willing to pay net 35 Euros for a mini bar that meets all their requirements.

The method of calculating the target cost is the process by which a company determines the estimated target selling price of its products or services and certain desired rate of return, with the difference of these factors is the amount of target costs. The formula to calculate the target costs can be represented as:

$$
\text { Target costs }=\text { Target price }- \text { Target profit }
$$


The amount of target costs must cover all the costs necessary for the production or purchase of products. According to the formula (1) determination of target prices is the first step in the process of determining the target cost. The target price is based on market research, competitor analysis and customer demands, but ultimately is determined by management or marketing department. Therefore, information about planned costs of product or service almost has no impact in the formation of the target price. A more significant role is played by the properties, the physical and aesthetic characteristics of products or services that are required by users.

The authors (Ansari et al., 1997) draw attention to the fact that market-determined price includes a number of factors. Sale price of existing products or price levels of competition are usually the starting point for determining the target cost. One of the well known concepts of determining target price is called the concept of perceived value (Cooper et al., 1999). According to the concept potential buyers will be willing to pay a higher price for a new product only if its value is greater. Therefore, the knowledge about the properties and characteristics of products or services which contributes to a certain perceived value of the product or service in terms of its potential customers is the key factor in determining the market or target prices.

Having defined the price of the product, the next step of the process of determining the target cost is the definition of the target gain. The amount of profit that the company wants to achieve by selling products or services should be based on long-term profit strategy, which is influenced by the market size, market share and sales volume. Cooper, R and Slagmulder, R. (1997) pointed out two ways of determining the target gain:

a) Target gain for a certain product can be determined based on the actual percentage of profit margins of its predecessor, which must be modified or adapted to market changes.

b) Another way to determine the average income based on the profit margin product lines which can then increase or decrease depending on market conditions.

S. Ansari, J. Bell, J. Cypher, P. Dears, J. Dutton, M. Ferguson, K. Hallin, C. Marx, C. Ross, and P. Zampino (1997) in their work used ROA (Return on Assets) indicator to determine a target gain. They emphasizes the necessity of analyzing planned production levels and overall business in terms of several years of production and profit plan. Expected percentage in return on assets (ROA), with previously established target price, determined the desired market share and as a consequences the required target gain, too.

Tamka (1993) use the following equation to calculate the target gain for a new product (Ps):

$$
P_{S}=\operatorname{ROS} x S a(2)
$$

where:

ROS - relative indicator of the profitability of sales,

Sa-target sales value 
The target sales value is calculated using retail prices according to the following equation:

$$
S a=R p \times Q p(3)
$$

where:

$R p$ - target retail price

$Q p$ - target production volume throughout the product lifecycle

Regardless of the choice of method for determining the target profit, target sales value must be sufficient to cover all costs in the lifetime of the product or service. Target gains may fluctuate due to changes in market conditions such as increases or decrease in demand for the product which will affect the product price.

Such alignment of the target profit is necessary for the lifetime of the product. If the company would not be adapted to suit the target gain to the new market conditions, it runs the risk that revenue from product sales is not sufficient to cover all the costs that will attach to a particular product during its lifetime.

The cost of the new product is determined on the basis of an existing product specifications and characteristics of the production process. Standard costs are costs that are planned to be incurred for the implementation of a specific effect under the so-called normal conditions, i.e. under conditions which usually arise. Standard costs are determined by unit specific performance using scientific methods and estimates based on historical data. They show how much should be the actual cost of direct materials, direct labor and overhead costs under normal operating conditions.

A direct part of standard cost per unit of output is determined on the basis of technical standards and standard price. The general standard cost per unit of output shall be determined during the process of accounting planning and be revised periodically in the event of significant changes in technology or cost of materials, labor or other costs. Standard costs of the new product are determined at a level that maintains really expected execution in the future. Actual costs are compared with standard costs and measure deviations.

The traditional model of cost accounting is unable to calculate accurately in today's market conditions. The system of standard costing is still considered as a significant information technology of management. However, its competence is at issue in the emerging dynamic operating conditions and as such is an unreliable tool for comparison with actual costs, and as such loses meaning.

Also, frequent changes in standards and adjustments in the process of determining the standard cost would require great expense and effort within the company. Applying standard cost and actual analysis of deviations from the standard cost is relevant in stable operating conditions without frequent changes in production technologies. 
Direct costs of mini bar components are shown in the following table:

\begin{tabular}{|l|l|l|l|}
\hline \multicolumn{1}{|c|}{ Components } & \multicolumn{1}{|c|}{ Function } & \multicolumn{1}{c|}{$\begin{array}{c}\text { Standard costs } \\
\text { (EUR) }\end{array}$} & $\begin{array}{c}\text { Share in the } \\
\text { overall standard } \\
\text { costs (\%) }\end{array}$ \\
\hline Box & storage & 55,00 & 80,90 \\
\hline Shelves & orderliness & 7,50 & 11,02 \\
\hline Ice cube tray & cooling & 2,50 & 3,68 \\
\hline Cup holder & $\begin{array}{l}\text { ensure the } \\
\text { consumption }\end{array}$ & 3,00 & 4,40 \\
\hline Total & & 68,00 & 100,00 \\
\hline
\end{tabular}

Tab. 2. Direct costs of mini bar components Source: Authors edition based on S. Ansari et al. (1997).

Overheads of mini bar service are 6 Euros.

Calculation of target cost of the product begins with the target net sales price that was previously defined by the requirements of the market. The amount of target costs derived from the net selling price seizure of the amount of the target profit and the general costs of production. The resulting target costs are compared with standard costs and measures the deviation. Table 3 . shows the calculating process of target cost.

\begin{tabular}{|l|l|}
\hline \multicolumn{2}{|l|}{ Calculating the target cost (EUR) } \\
\hline Net selling price & 35,00 \\
\hline - estimated target gain $\mathbf{( 1 5} \% \mathbf{)}$ & 5,25 \\
\hline - overheads & 6,00 \\
\hline Target cost & 23,75 \\
\hline Standard costs & 68,00 \\
\hline Deviation & $-44,25$ \\
\hline
\end{tabular}

Tab. 3. Calculating the target cost

Source: Authors' edition based on S. Ansari et al. (1997).

Table 3. shows that deviation value between target cost and standard cost is 44.25 euro, because the standard costs exceed the target costs it is necessary to undertake some redesign actions of the product in order to achieve additional savings and reduce production costs. The redesigning process should focus on those components of the product that are important to customers. Therefore, the next step is to analyze the impact of individual components and properties of the mini bar services. 


\begin{tabular}{|c|c|c|c|c|}
\hline \multirow{2}{*}{ Properties } & \multicolumn{4}{|c|}{ Components } \\
\hline & Box & Shelves & Ice cube tray & Cup holder \\
\hline Wide choice & 20 & 35 & 25 & 20 \\
\hline Design & 50 & 5 & 15 & 30 \\
\hline Dimensions & 30 & 10 & 20 & 40 \\
\hline $\begin{array}{l}\text { Economic } \\
\text { characteristics }\end{array}$ & 40 & 25 & 30 & 5 \\
\hline Utilization & 75 & 25 & 0 & 0 \\
\hline
\end{tabular}

Tab. 4. Effect of individual components on the properties of the product's requirements from the market $(\%)$

Source: Authors' edition based on S. Ansari et al. (1997).

The data in the Table 4 . indicate that the wide choice, that customers cite as an important characteristic: the most responsible components of the shelves, and box is indespensible for the design. Current data are a good basis for analysis of the impact of individual components on customer satisfaction. It can be carried out if the effects of individual components on the properties (Table 4.) will be multiplied by the preferences data of properties (Table 1.). Table 5. shows the impact of individual components on customer satisfaction.

\begin{tabular}{|c|c|c|c|c|}
\hline \multirow{2}{*}{ Properties } & \multicolumn{4}{|c|}{$\begin{array}{l}\text { Market significant rate* component influence } \\
\text { on the properties }\end{array}$} \\
\hline & Box & Shelves & Ice cube tray & Cup holder \\
\hline Wide choice & 6,67 & 11,66 & 8,33 & 6,67 \\
\hline Design & 13,33 & 1,33 & 4,00 & 8,00 \\
\hline Dimensions & 4,00 & 1,33 & 2,66 & 5,33 \\
\hline $\begin{array}{l}\text { Economic } \\
\text { characteristics }\end{array}$ & 2,67 & 1,67 & 2,00 & 0,33 \\
\hline Utilization & 15,00 & 5,00 & 0,00 & 0,00 \\
\hline Total & $41,67 \%$ & $20,99 \%$ & $16,99 \%$ & $20,33 \%$ \\
\hline Rang & 1 & 2 & 4 & 3 \\
\hline
\end{tabular}

Tab. 5. Impact of individual components on customer satisfaction Source: Authors' edition based on S. Ansari et al. (1997). 
Table 5. shows the values of the impact of individual components on the properties of the product and the market assessment of importance of certain properties of the mini bar. The results show that according to potential customer's answers the most important component of the product is the box. This matrix can be used to make a decision about which components of the product managers should turn with the aim to reduce costs.

Measuring the deviation value of target cost from the standard cost in the level of components of product can be carried out in such a way. Target cost of each component shall be determined by multiplying the percentage value of their contributions (Table 5.) with the total cost of a specific target product.

\begin{tabular}{|l|l|l|l|}
\hline \multicolumn{1}{|c|}{$\begin{array}{c}\text { Components } \\
\text { of } \\
\text { product }\end{array}$} & \multicolumn{1}{|c|}{$\begin{array}{c}\text { Target } \\
\text { costs }\end{array}$} & \multicolumn{1}{|c|}{$\begin{array}{c}\text { Standard } \\
\text { costs }\end{array}$} & $\begin{array}{c}\text { Deviation of target } \\
\text { cost from standard } \\
\text { costs }\end{array}$ \\
\hline Box & $23,75^{*} 0,4167=9,89$ & 55 & $-45,11$ \\
\hline Shelves & $23,75^{*} 0,2099=4,98$ & 7,5 & $-2,52$ \\
\hline Ice cube tray & $23,75^{*} 0,1699=4,04$ & 2,5 & 1,54 \\
\hline Cup holder & $23,75^{*} 0,2033=4,83$ & 3 & 1,83 \\
\hline Total & 23,75 & 68 & $-44,25$ \\
\hline
\end{tabular}

Tab. 6. Deviation of target cost from standard cost in the level of components Source: Authors' edition based on S. Ansari et al. (1997).

The measurement deviation value of target cost from the standard cost in the level of components of product give a more detailed analysis to management decisions to reach a target cost.

The process of developing and implementing target cost method in the Hospitality Industry has been shown through several steps. R. Cooper and R. Slagmulder (1997) identified many factors that affect the phases of development of the target cost method, among others these are: competition, changes in consumer demand, manufacturing strategies, the degree of connectivity with customers etc. Target costs represent a market-oriented cost management model, therefore management efforts to achieve the target cost should bear in mind those characteristics of product which are required from market. In other words, a key factor of success in the target costing method is customer satisfaction. The survey of customer satisfaction must be frequently carried out to determine the position of the product on the market and to identify further actions for improvement. Therefore, the competition and the behavior of competitors represent another important factor in the success of the application of the methods of target costs. Also, the relationship with customers is a very important factor to achieve competitive advantages.

Margaret L. Gagne and Richard Discenza (1995) argue that the implementation of the target costing method brings more benefits for those companies that produce heterogeneous products. Diversified product lines, use of technology for factory 
automation (including computer-aided design, flexible manufacturing systems, automation of office management and computer-aided manufacturing), have a shorter life cycle (ie shorter production cycle), developing systems to reduce costs during the planning, design and development phases of the product life cycle, apply management techniques such as Just-In-Time, value engineering and quality management.

\section{CONCLUSIONS}

Introducing elements of target costs led to a change in the role of cost accounting and it has become more internally oriented. Therefore, a method of target costs is a modern complex management-accounting concept that focuses on reducing costs throughout the product life cycle, from production planning and product design, to its production, distribution and maintenance.

The objective of target costing is to assure that a firm achieves its product specific and firm-wide profit objectives in a very competitive market environment. It is becoming increasingly essential in service industry, also, as more firms are realizing that they cannot increase prices to solve cost and profit squeeze problems.

Target costing model represents a reliable method for managing and reducing the cost of which is focused on the idea of closely integrating strategic variables within the concept of the product. Thus this model is an integral part of the product development process and contributes to the management and reduction of costs in the earliest stages of its life cycle, that is already in the design phase of the product. Implementing the target costing method will take time. It requires widespread education, the support of senior management, the involvement of all parts of the organization, and a strong, proactive role on the part of the management accountant. This article is intended to provide a concise introduction to target costing, its implementation, and its benefits in the hospitality industry. 
Journal of Education Culture and Society No. 2_2014

\section{REFERENCES}

Ansari, S., Bell, J., Cypher, J., Dears, P., Dutton, J., Ferguson, M., Hallin, K., Marx, C., Ross, C., \& Zampino, P. (1997). Target Costing: the next Frontier in Strategic Cost

Management. New York: McGraw-Hill.

Ansari, S., Bell, J., Klammer, T., \& Lawrence, C. (1997). Strategy and Management Accounting: Version 1.1. USA: Richard D. Irwin.

Ansari, S., Swenson, D., Bell, J., \& Kim, L.W. (2003). Best Practice in Target Costing. Management Accounting Quarterly, 4, (2). Winter, 12-17.

Cooper, R, \& Slagmulder, R. (1997). Factors Influencing the Target Costing Process: Lessons from Japanese Practice. Working Paper Series, 97/30, University of Ghent.

Cooper, R, \& Slagmulder, R. (2002). Target costing for New-Product Development: Component-Level Target Costing. Journal of Cost Management, 16 (5), 36-43.

Cooper, R. \& Slugmulder, R. (1999). Develop Profitable New Products With Target Costing. MIT Sloan Management Review, 40, (4), 23-33.

Fiel, P., Yook, K.H., \& Kim, L.W. (2004). Japanese Target Costing: A Historical Perspective. International Journal of Strategic Cost Management, 2, (4),Spring, 10-19.

Gagne, M. L., \& Discenza, R. (1995). Target costing. Journal of Business and Industrial Marketing, 10, (1.),16-22.

Garrison, R., Noreen, E., \& Brewer, P. (2004). Managerial Accounting, 11th ed. New York: McGraw-Hill Irwin.

Hilton, R, W. (2008). Managerial accounting creating value in a dynamic business Environment. 7th ed. New York: McGraw-Hill Irwin.

Horvath, P., Gleich, R., and Schmidt, S. (1998). Linking Target Costing to ABC at a U.S. Automotive Supplier. Journal of Cost Management, 12, (2), March/April, 16-22.

Langfield-Smith, K., Thorne, H., \& Hilton, R.W. (2006). Management Accounting 4e: Information for Managing and Creating Value, 4th ed. Sydney. NSW: McGraw-Hill.

Monden, Y. (1995). Cost Reduction Systems: Target Costing and Kaizen Costing. Portland, Oregon: Productivity Press.

Monden, Y., \& Hamada, K. (1991). Target costing and kaizen costing in Japanese automobile companies. Journal of Management Accounting Research, 3, 16-34.

Sakurai, M. (1989). Target costing and how to use it. Journal of Cost Management, Summer, 39-50.

Tanaka, T (1993). Target Costing at Toyota. Journal of Cost Management, Spring, 4-11.

Tani, T., \& Kato, Y. (1994). Target Costing in Japan. In: K. Dellmann, and K. P. Franz (Ed.), Neuere Entwicklungen im Kostenmanagement (pp.191-222). Bern-Stuttgart-Wien: Verlag Paul Haupt. 